\section{Arkivoc

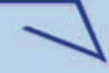

Archive for

Organic Chemistry
The Free Internet Journal

for Organic Chemistry
Paper

Arkivoc 2017, part ii, 7-11

\title{
The Niementowski reaction of anthranilic acid with ethyl acetoacetate revisited: a new access to pyrano[3,2-c]quinoline-2,5-dione
}

\author{
Yevgen M. Poronik, Jan Klajn, Wioleta Borzęcka, and Daniel T. Gryko*
}

Institute of Organic Chemistry, Polish Academy of Sciences, 44/52 Kasprzaka, 01-224 Warsaw, Poland Email: dtgryko@icho.edu.pl

\section{Dedicated to Prof. Jacek Mlochowski on the occasion of his 80th anniversary}

Received 02-20-2016

Accepted 05-13-2016

Published on line 06-13-2016

\section{Abstract}

The reaction of anthranilic acid with ethyl acetoacetate gives rise directly to 4-methylpyrano[3,2-c]quinoline2,5-dione. The mechanism is assumed to involve condensation of the initial product with a second molecule of the $\beta$-ketoester. None of the expected compound (2-methyl-4-oxo-1,4-dihydroquinoline-3-carboxylic acid) is formed in the reaction.

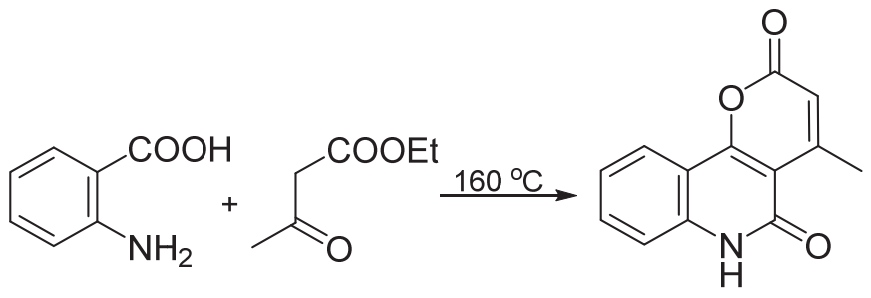

Keywords: Fused quinolines, fused pyrans, ring closure, anthranilic acid, Niementowski reaction 


\section{Introduction}

Pyrano[3,2-c]quinoline-2,5-diones and their analogues display some biological activity. ${ }^{1}$ The prime example is compound 1, (Figure 1) which serves as precursor for the synthesis of pyroquilon derivatives used as fungicides. $^{2}$ The derivative $\mathbf{2}$ is reported to have potent antibacterial activity. ${ }^{3}$ The structurally related pyranoquinolone alkaloid $\mathbf{3}$ has been shown to exhibit SRS-A antagonist action. ${ }^{4}$ It was isolated from two East African Fagara species.

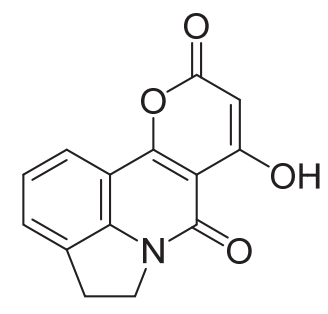

1<smiles>Cn1c(=O)c2c(O)c(-c3ccccc3)c(=O)oc2c2ccccc21</smiles>

2<smiles>Cn1c(=O)c2c(c3ccccc31)OC(C)(C)C=C2</smiles>

3

\section{Figure 1}

Various methods have been reported for the synthesis of pyrano[3,2-c]quinoline-2,5-diones. ${ }^{5-12}$ Very $^{-}$ recently, Hajra and co-workers published a regioselective synthesis of pyrano[3,2-c]quinolin-2-ones from 4-hydroxy-1-methyl-2-quinolone and chalcones. ${ }^{13}$

\section{Results and Discussion}

Among many different methods for the synthesis of quinolin-4-one derivatives, ${ }^{1}$ there is one in an old report by Niementowski. ${ }^{14}$ He claimed that simple heating of anthranilic acid with an excess of ethyl acetoacetate gave the corresponding 4-quinolone 6 in 8-12\% yield (Scheme 1). As a part of a broader project aiming at heterocyclic functional dyes, we decided to use this method to prepare significant quantities of the acid 6 . On repeating the reaction, and following the suggested work-up according to Niementowski's original procedure, we found that the desired product was not formed. This finding was further confirmed by MS studies of the crude reaction mixture using different ionization techniques. Moreover, from the condensation of ethyl acetoacetate with anthranilic acid, we were able to separate a high-melting colourless solid (7) by simple filtration of the crude reaction mixture. Interestingly, careful reading of Niementowski's paper revealed that besides compound 6 (with reported melting point $240{ }^{\circ} \mathrm{C}$ ), an unidentified compound (8) also was isolated as a poorly soluble colourless solid (Scheme 1). Using methods available to him in the late $19^{\text {th }}$ century, the author failed to establish the structure of this compound. Based solely on its elemental analysis, he assigned to it the molecular formula $\mathrm{C}_{22} \mathrm{H}_{16} \mathrm{~N}_{2} \mathrm{O}_{5}$ (found: $\mathrm{C} 68.44, \mathrm{H} \mathrm{4.20,} \mathrm{N} 7.11$ and 6.73 (two measurements were reported) \%; calcd. C 68.04, H 4.12, N $7.22 \%)$. 
<smiles>Cc1cc(=O)oc2c1c(=O)[nH]c1ccccc12</smiles>

A<smiles>Cc1cc(=O)oc2[nH]c3ccccc3c(=O)c12</smiles>

B

Figure 2. Possible structures of compound 7.

The mass spectrum of our high-melting product 7 showed a molecular ion at 227, which does not correspond to the formula suggested by Niementowski. The high resolution MS established the molecular formula as $\mathrm{C}_{13} \mathrm{H}_{9} \mathrm{NO}_{3}$. To resolve the structure of compound 7 we performed a set of spectral studies. While the ${ }^{1} \mathrm{H}$ NMR spectrum matches well with both possible isomeric structures $\mathbf{A}$ and $\mathbf{B}$ (Fig. 2), the ${ }^{13} \mathrm{C}$ NMR spectrum corresponds well only with structure $A$. The carbonyl carbon atom in the quinolin-4(1H)-one fragment should show a signal at around $180 \mathrm{ppm}$, while the signals of $2 H$-chromen-2-one and quinolin-2(1H)one fragments show their ester and amide signals at around 160-165 ppm (see Supporting Information). Data from other NMR techniques (COSY, NOESY, ${ }^{1} \mathrm{H}-{ }^{13} \mathrm{C} \mathrm{HSQC},{ }^{1} \mathrm{H}-{ }^{13} \mathrm{C} \mathrm{HMBC}$ and ${ }^{1} \mathrm{H}-{ }^{15} \mathrm{~N} \mathrm{HSQC}$ ) fit both structures $\mathbf{A}$ and $\mathbf{B}$. In the IR spectrum of compound 7, there is no characteristic intense band at around $3300-3400 \mathrm{~cm}^{-1}$ which would demonstrate the $\mathrm{N}-\mathrm{H}$ bond in the structure $\mathbf{B}$. Therefore both NMR and IR spectroscopy suggest that compound 7 possesses the structure of 4-methylpyrano[3,2-c]quinoline-2,5(6H)-dione (A, Fig. 2; Scheme 1). It is noteworthy that the calculated elemental analysis for carbon and hydrogen (but not for nitrogen) for compound 7 ( $\mathrm{C} 68.72, \mathrm{H} 3.99, \mathrm{~N} 6.16 \%$ ) fits well the original combustion analysis performed by Niementowski for his unknown product $\mathrm{C}_{22} \mathrm{H}_{16} \mathrm{~N}_{2} \mathrm{O}_{5}$ (found: $\mathrm{C} 68.44, \mathrm{H} \mathrm{4.20,} \mathrm{N} 7.11$ and 6.73 (two measurements) \%). Niementowski reported that his product melts at $355^{\circ} \mathrm{C}$ with decomposition and blackening, and this is what we observed for compound 7. Product $\mathbf{7}$ is only sparingly soluble in most organic solvents. The angular fusion of three unsaturated rings results in strong absorption of ultraviolet light. The absorption maximum appears at $377 \mathrm{~nm}$. Compound 7 displays no fluorescence either in polar or in non-polar solvents.<smiles>Cc1[nH]c2ccccc2c(=O)c1C(=O)O</smiles>

6

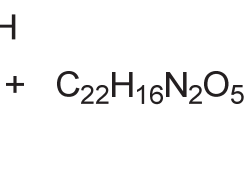

8

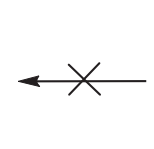<smiles>Nc1ccccc1C(=O)O</smiles>

4

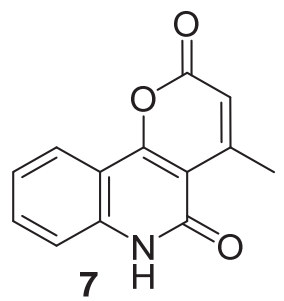

5

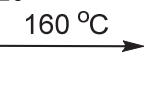

Scheme 1. The reaction of anthranilic acid with ethyl acetoacetate.

We are not aware of any earlier attempt to assign the structure of Niementowski's product. 4-Methylpyrano[3,2-c]quinoline-2,5(6H)-dione (7) has been reported twice as a product of multistep reactions. Kappe and Mayer reported that 4-hydroxyquinolin-2-ones undergo condensation with $\beta$-keto-esters to give pyrano[3,2-c]quinoline-2,5(6H)-diones in good yields. ${ }^{11}$ The same reaction, albeit catalysed by pyridine, was later reported by Kumar and Rajendran. ${ }^{12}$ 
The structure of compound $\mathbf{7}$ suggests the following mechanism. Initially, condensation of anthranilic acid with one equivalent of ethyl acetoacetate occurs. The acetyl group of the intermediate $\mathbf{9}$ is reactive enough to allow a Knoevenagel-type cyclization with a second molecule of ethyl acetoacetate, followed by a deacetylation process (Scheme 2). It appears that the second condensation occurs faster than the first. When the reaction was carried out with equimolar amounts of anthranilic acid and ethyl acetoacetate, pyrano[3,2c]quinoline-2,5-dione 7 was again formed.

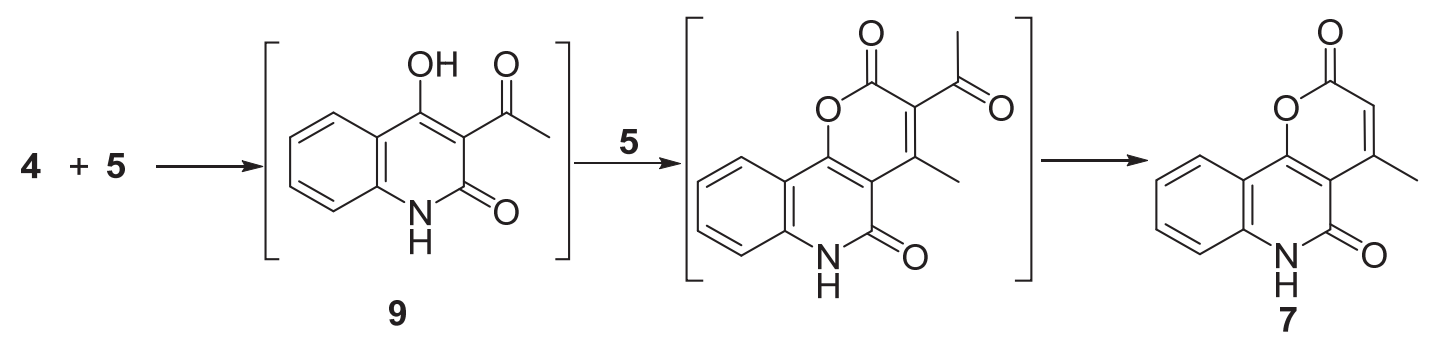

Scheme 2. A possible route to the formation of compound 7.

\section{Conclusion}

It was found that the condensation of anthranilic acid with ethyl acetoacetate gives rise directly to a pyrano[3,2-c]quinoline-2,5-dione derivative (7) instead of 2-methyl-4-oxo-1,4-dihydroquinoline-3-carboxylic acid (6) as originally reported by Niementowski. This result is not only of theoretical significance in that it provides a new insight into factors influencing the course of the reaction of 2 -aminobenzoic acids with $\beta$-ketoesters, but it may also open the door to practical applications. Pyranoquinolones possess synthetic handles and thus can serve as platforms to obtain more complex systems based on this fused heterocycle.

\section{Experimental Section}

General. ${ }^{1} \mathrm{H}$ NMR and ${ }^{13} \mathrm{C}$ NMR were recorded on a Varian VNMRS $600\left({ }^{1} \mathrm{H}: 600 \mathrm{MHz},{ }^{13} \mathrm{C}: 150 \mathrm{MHz}\right)$ The chemical shifts $(\delta)$ and coupling constants $(J)$ are expressed in ppm and Hertz respectively. UV-Vis spectra were recorded on a Perkin-Elmer Lambda 25 spectrophotometer. Melting points were determined using a Büchi-Tottoli apparatus. Reagents and starting materials were directly used as obtained commercially.

Preparation of 4-methylpyrano[3,2-c]quinoline-2,5-dione (7). In a round-bottomed flask equipped with condenser, a mixture of anthranilic acid $(5 \mathrm{~g}, 36.5 \mathrm{mmol})$ and ethyl acetoacetate $(7 \mathrm{~g}, 53.8 \mathrm{mmol})$ was placed and heated at $130{ }^{\circ} \mathrm{C}$ for $40 \mathrm{~h}$. Subsequently the temperature was raised to $160{ }^{\circ} \mathrm{C}$ and the reaction was heated for a further $40 \mathrm{~h}$. After cooling, the suspension was filtered and washed with $n$-amyl alcohol. The final product was obtained as white crystals $(1.33 \mathrm{~g}, 16 \%) . \mathrm{Mp}>300^{\circ} \mathrm{C}$ (decomp.). IR $\left(\mathrm{KBr}, \mathrm{cm}^{-1}\right)$ : 2999, 2843, 1742, 1657, 1266. UV-VIS (DMSO, nm) 256, 316, 329, 361, 377. ${ }^{1} \mathrm{H}$ NMR $\left(600 \mathrm{MHz}\right.$, DMSO- $\left.d_{6}\right): \delta_{\mathrm{H}} 2.60\left(3 \mathrm{H}, \mathrm{s}, \mathrm{CH}_{3}\right)$, $6.31(1 \mathrm{H}, \mathrm{s}, \mathrm{ArH}), 7.29(1 \mathrm{H}, \mathrm{t}, J 8.0 \mathrm{~Hz}, \mathrm{ArH}), 7.36(1 \mathrm{H}, \mathrm{d}, J 7.8 \mathrm{~Hz}, \mathrm{ArH}), 7.65(1 \mathrm{H}, \mathrm{t}, J 8.0 \mathrm{~Hz}, \mathrm{ArH}), 7.97(1 \mathrm{H}, \mathrm{d}, J$ 8.4 Hz, ArH), $11.94(1 \mathrm{H}, \mathrm{s}, \mathrm{NH}) .{ }^{13} \mathrm{C} N M R\left(150 \mathrm{MHz}, \mathrm{DMSO}-d_{6}\right): \delta_{\mathrm{C}} \mathrm{d} 22.8,108.4,112.3,113.7,115.9,123.0$, 
123.4, 133.6, 139.1, 157.0, 158.9, 160.0, 160.4. HRMS (EI) $m / z$ MS $227.1[\mathrm{M}]^{+}$calcd for $\mathrm{C}_{13} \mathrm{H}_{9} \mathrm{NO}_{3}: 227.0582$, found: 227.0578. Anal. Calc. for $\mathrm{C}_{13} \mathrm{H}_{9} \mathrm{NO}_{3} \cdot 0.1 \mathrm{H}_{2} \mathrm{O}$ : C 68.18; $\mathrm{H} 4.05 ; \mathrm{N} 6.12$; found: C 67.96; $\mathrm{H} 3.85 ; \mathrm{N} 5.85 \%$.

\section{Acknowledgements}

Financial support of our work from the Foundation for Polish Science (Grant number TEAM/2009-4/3) is gratefully acknowledged.

\section{References}

1. Ball, P. In The Quinolones; Andriole, V. T. Ed.; 2nd Edn.; Academic Press: London, 1998; pp 1-28.

2. Kappe, C. O.; Kappe, T. J. Heterocycl. Chem. 1989, 26, 1555.

http://dx.doi.org/10.1002/jhet.5570260609

3. Choi, S.; Branstrom, A.; Gothe, S. A.; Lipman, R.; Tamilarasu, N.; Wilde, R.G. Heterocyclic inhibitors of bacterial peptidyl tRNA hydrolase and uses thereof. W.O. 2008/127274 A2, October 23, 2008

4. Kamikawa, T.; Hanaoka, Y.; Fujie, S.; Saito, K.; Yamagiwa, Y.; Fukuhara, K.; Kubo, I. Bioorg. Med. Chem. 1996, 4, 1317. http://dx.doi.org/10.1016/0968-0896(96)00110-1

5. Kmetic, M.; Stanovnik, B.; Tisler, M.; Kappe, T. Heterocycles, 1993, 35, 1331. http://dx.doi.org/10.3987/COM-93-S(T)135

6. Kralj, L. Hvala, A. Svete, J. Golic, L. Stanovnik B. J. Heterocycl. Chem. 1997, 34, 247. http://dx.doi.org/10.1002/jhet.5570340137

7. Mulwad, V. V.; Hegde, A. S.; Suryanarayan, V. Indian J. Chem., Sect. B: 1999, 38, 148.

8. Ngadjui, B. T.; Ayafor, J. F.; Bilon, A. E.; Sondengam, B. L.; Connolly, J. D.; Rycroft, D. S. Tetrahedron 1992 , $48,8711$.

http://dx.doi.org/10.1016/S0040-4020(01)89446-1

9. Schmidt, H. W.; Junek, H. Monatsh. Chem. 1978, 109, 1075.

http://dx.doi.org/10.1007/BF00913010

10. Abbaspour-Gilandeh, E.; Azimi, S. C. Iran. Chem. Commun. 2015, 3, 218.

11. Kappe, T.; Mayer, C. Synthesis 1981, 524. http://dx.doi.org/10.1055/s-1981-29509

12. Kumar, N. V.; Rajendran, S. P. Heterocycl. Commun. 2004, 10, 289.

13. Bagdi, A. K.; Hajra, A. RSC Adv. 2014, 4, 23287. http://dx.doi.org/10.1039/c4ra03221g

14. Niementowski, S. Chem. Ber. 1894, 27, 1394. http://dx.doi.org/10.1002/cber.18940270242 